\title{
HUBUNGAN KONSEP DIRI PADA REMAJA TERHADAP KEMAMPUAN MENGHADAPI PERILAKU BULLYING DI SMKN 2 PEKANBARU
}

\author{
Muhammad Hadyan Nubli. M', Erna Marni ${ }^{2}$, Yecy Anggreny ${ }^{3}$ \\ ${ }^{1,2,3}$ PSIK STIKes HTP \\ Program Studi Ilmu Keperawatan STIKes Hang Tuah Pekanbaru Jalan Mustafa Sari No 5 \\ Tangkerang Selatan Pekanbaru \\ Telepon 085263092297 Email:hadyannubli@gmail.com
}

\begin{abstract}
ABSTRAK
Bullying di sekolah merupakan kasus yang sering didengar dan banyak terjadi hingga saat ini serta belum bisa berhenti. Hal ini berdampak terhadap perkembangan psikologi pada remaja. Sekolah seharusnya menjadi tempat yang menyenangkan, namun bullying di sekolah berubah menjadi tempat yang mengerikan, bahkan mengancam jiwa. Menghadapi perilaku bullying ini diperlukan suatu cara, salah satunya dengan mempunyai konsep diri yang positif. Penelitian ini bertujuan untuk mengetahui hubungan konsep diri pada remaja terhadap kemampuan menghadapi perilaku bullying. Penelitian ini menggunakan desain deskriptif korelasi dengan pendekatan cross sectional. Penelitian ini dilakukan di SMKN 2 Pekanbaru pada kelas X dan XI menggunakan teknik quota sampling dengan sampel berjumlah 333 orang. Hasil analisa univariat diperoleh sebagian besar konsep diri yang positif pada remaja berjumlah 178 orang (53,5\%), kemampuan menghadapi perilaku bullying positif berjumlah 180 orang $(54,1 \%)$, hubungan konsep diri pada remaja terhadap kemampuan menghadapi perilaku bullying di SMKN 2 Pekanbaru ( $p$ value $=0,000<0,05$ ). Kesimpulan pada penelitian ini diketahui bahwa ada hubungan yang signifikan antara konsep diri pada remaja terhadap kemampuan menghadapi perilaku bullying di SMKN 2 Pekanbaru. Diharapkan bagi remaja untuk dapat mengembangkan konsep diri yang positif dengan cara mengikuti kegiatan positif yang ada disekolah seperti aktif mengikuti kegiatan ekstrakurikuler, bergabung didalam OSIS.
\end{abstract}

Kata kunci : Bullying, Konsep Diri, Remaja

\section{ABSTRACT}

Bullying in schools is a case which is commonly heard; often occurs and unstoppable until the moment. It affects adolescents' mental development. Schools should be a fun place, but bullying at school turns into a horrible, even life-threatening place. Facing this bullying behavior requires a way, one of which is to have a positive self-concept. This research was designed by descriptive correlation with cross sectional approach. This research was conducted in SMKN 2 Pekanbaru at class X, XI with quota sampling technique and sample amounted 333 people. Univariate analysis results which was obtained shows that positive selfconcepts in adolescents amounted to 178 people (53.5\%), and the ability to face positive bullying behavior amounted to 180 people $(54,1 \%)$, correlation between self-concept in adolescents against the ability to face the bullying behavior in SMKN 2 Pekanbaru $(p$ value $=0,000<0,05)$. The conclusion in this research was found that there was significant correlation between self-concept in adolescents and the ability to face bullying behavior in SMKN 2 Pekanbaru. It is expected that adolescents can develop positive self-concept by participating in positive activities at school such as extracurricular and join student council (OSIS).

Keywords : Bullying, Self-Concept, Adolescents

\section{PENDAHULUAN}

Bullying di sekolah merupakan kasus yang sering didengar dan banyak terjadi hingga saat ini serta belum bisa berhenti. Sekolah seharusnya menjadi tempat yang menyenangkan, namun bullying di sekolah berubah menjadi tempat yang mengerikan, bahkan mengancam jiwa (Abdullah, 2013)

Kasus bullying di dunia oleh teman sekolah pada beberapa negara sangat tinggi. Pada tahun 2015 di Nepal angka bully mencapai 51\%. Tahun 2016 di Myanmar mencapai 50\% (WHO, 2017). Beberapa 
Muhammad Hadyan Nubli. M${ }^{1}$, Erna Marni², Yecy Anggreny ${ }^{3}$, Hubungan Konsep Diri Pada Remaja Terhadap Kemampuan Menghadapi Perilaku Bullying Di Smkn 2 Pekanbaru

negara di Asia, Amerika, Eropa prevalensi kasus bullying yang terjadi di sekolah diperkirakan sekitar 8\%-50\% kasus sehingga angka tersebut dapat dikatakan tinggi (Soedjatmiko dkk, 2013). KPAI mencatat korban bully yang terjadi di Indonesia sebanyak 26 ribu kasus sejak tahun 2011-2017 (KPAI, 2017).

Beberapa kasus bullying yang dinyatakan Pandegrass (2014) di dunia terjadi pada remaja. Tahun 2012 di Kanada yang menjadi korban yaitu remaja perempuan berusia 15 tahun kelas 10 SMA dimana korban tersebut memutuskan untuk bunuh diri setelah di bully oleh teman-teman sekolah secara langsung dan via internet. Di Florida tahun 2012 seorang remaja perempuan berusia 16 tahun juga melakukan bunuh diri akibat di bully penampilannya dan harga dirinya (Pandegrass, 2014).

Kasus bully juga pernah terjadi di SMAN 3 Jakarta pada tahun 2016 dimana seorang kakak kelas terekam video sedang mengintimidasi adik kelas. Mereka terlihat menyiksa adik kelas sebagai korban dengan membuang abu rokok ke kepala kemudian disiram dengan air minuman kemasan. Korban juga dipermalukan dengan diminta menghisap rokok dan mengenakan bra di luar seragam (KPAI, 2016).

Bullying pada remaja rentan terjadi akibat tingginya ego serta masih labil secara emosional pada remaja. Pada usia ini remaja lagi dalam masa gemar dalam mencari pertemanan. Tingginya ego serta tingkat emosional yang masih labil ini menyebabkan remaja rentan terjadi konflik dan akhirnya berujung pada bullying (Khoirunnisa, 2015).

Remaja pada umumnya didefinisikan sebagai masa transisi atau masa peralihan yang sebelumnya dari masa anak-anak menuju masa dewasa dengan rentang usia 12 tahun sampai 21 tahun (Dewi, 2012). Pada masa remaja akan mengalami beberapa perubahan yang ditandai dengan berubahnya beberapa aspek seperti, aspek fisik, aspek psikis, dan aspek psikologis. Terdapat perkembangan yang sangat penting pada fase remaja ditandai dengan mulai matang organ fisik secara seksual sehingga dapat bereproduksi (Dewi, 2012).

Lingkungan hidup pada remaja menjadi hal yang sangat berpengaruh terhadap proses pembentukan konsep diri pada remaja. Jika berada dalam lingkungan yang positif, hal ini membuat konsep diri yang positif pula pada remaja. Sebaliknya jika berada dalam lingkungan yang negatif maka dapat membuat konsep diri yang negatif pula pada remaja tersebut (Herdyanti \& Margaretha, 2016)

Konsep diri merupakan kesadaran dari batin yang tetap, tentang pengalaman dari individu tersebut dan juga yang membedakan antara individu tersebut dengan individu lainnya (Sobur, 2011).Konsep diri ini merupakan bagian inti dari pengalaman individu. Secara perlahan-lahan pengalaman tersebut dibedakan dan disimbolisasikan sebagai bayangan diri tentang siapa individu 
tersebut sebenarnya dan apa yang seharusnya diperbuat oleh individu tersebut (Sobur, 2011)

Penelitian Herdyanti dan Margaretha (2016) yang dilakukan pada remaja di daerah Surabaya menunjukan bahwa konsep diri memiliki hubungan terhadap kecenderungan penerimaan perilaku bullying. Dari hasil penelitian yang dilakukan menunjukan bahwa semakin positif konsep diri yang dimiliki remaja maka semakin rendah kecenderungan yang dimiliki untuk menjadi korban bullying, sebaliknya semakin negatif konsep diri yang dimiliki remaja maka semakin tinggi pula kecenderungannya untuk menjadi korban bullying.

Berdasarkan latar belakang yang terjadi di atas, maka peneliti tertarik untuk mengetahui apakah ada "hubungan konsep diri pada remaja terhadap kemampuan menghadapi perilaku bullying".

\section{METODE PENELITIAN}

Penelitian ini menggunakan desain deskriptif korelasi dengan pendekatan cross sectional. Penelitian ini dilakukan di SMKN 2 Pekanbaru pada kelas X dan XI menggunakan teknik quota sampling dengan sampel berjumlah 333 orang. Alat pengumpulan data yang digunakan berbentuk kuesioner. Analisa yang digunakan adalah analisa univariat dan analisa bivariat dengan uji chi-square.

\section{HASIL PENELITIAN}

\section{Tabel 1}

Distribusi Frekuensi Responden Menurut Jenis Kelamin Di SMKN 2 Pekanbaru

\begin{tabular}{cccc}
\hline No & $\begin{array}{c}\text { Jenis } \\
\text { Kelamin }\end{array}$ & Frekuensi & $\mathbf{( \% )}$ \\
\hline 1 & Laki-laki & 251 & 75,4 \\
\hline 2 & Perempuan & 82 & 24,6 \\
\hline & Jumlah & 333 & 100 \\
\hline
\end{tabular}

Dapat dilihat distribusi frekuensi jenis kelamin responden laki-laki sebanyak 251 orang dengan persentase $75,4 \%$ dan perempuan sebanyak 82 orang dengan persentase $24,6 \%$.

\section{Tabel 2}

Distribusi Frekuensi Konsep Diri Pada Remaja

\begin{tabular}{cccc}
\hline No & Konsep Diri & Frekuensi & $(\%)$ \\
\hline 1 & Positif & 178 & 53,5 \\
\hline 2 & Negatif & 155 & 46,5 \\
\hline & Jumlah & 333 & 100 \\
\hline
\end{tabular}

Dapat dilihat distribusi frekuensi konsep diri remaja dari 333 responden diperoleh hasil bahwa mayoritas remaja di SMKN 2 Pekanbaru memiliki konsep diri yang positif dengan jumlah 178 orang $(53,5 \%)$.

\section{Tabel 3}

Distribusi Frekuensi Kemampuan Menghadapi Perilaku Bullying

\begin{tabular}{cccc}
\hline No & Bullying & Frekuensi & $(\%)$ \\
\hline 1 & Positif & 180 & 54,1 \\
\hline 2 & Negatif & 153 & 45,9 \\
\hline & Jumlah & 333 & 100 \\
\hline
\end{tabular}

Dapat dilihat distribusi frekuensi kemampuan menghadapi perilaku bullying dari 333 responden diperoleh hasil bahwa mayoritas remaja di SMKN 2 Pekanbaru 
Muhammad Hadyan Nubli. M${ }^{1}$, Erna Marni², Yecy Anggreny ${ }^{3}$, Hubungan Konsep Diri Pada Remaja Terhadap Kemampuan Menghadapi Perilaku Bullying Di Smkn 2 Pekanbaru

memiliki kemampuan menghadapi perilaku

bullying yang positif dengan jumlah 180 orang

$(54,1 \%)$.

\section{Tabel 4}

Konsep Diri Remaja Terhadap Kemampuan Menghadapi Perilaku Bullying Di SMKN 2 Pekanbaru

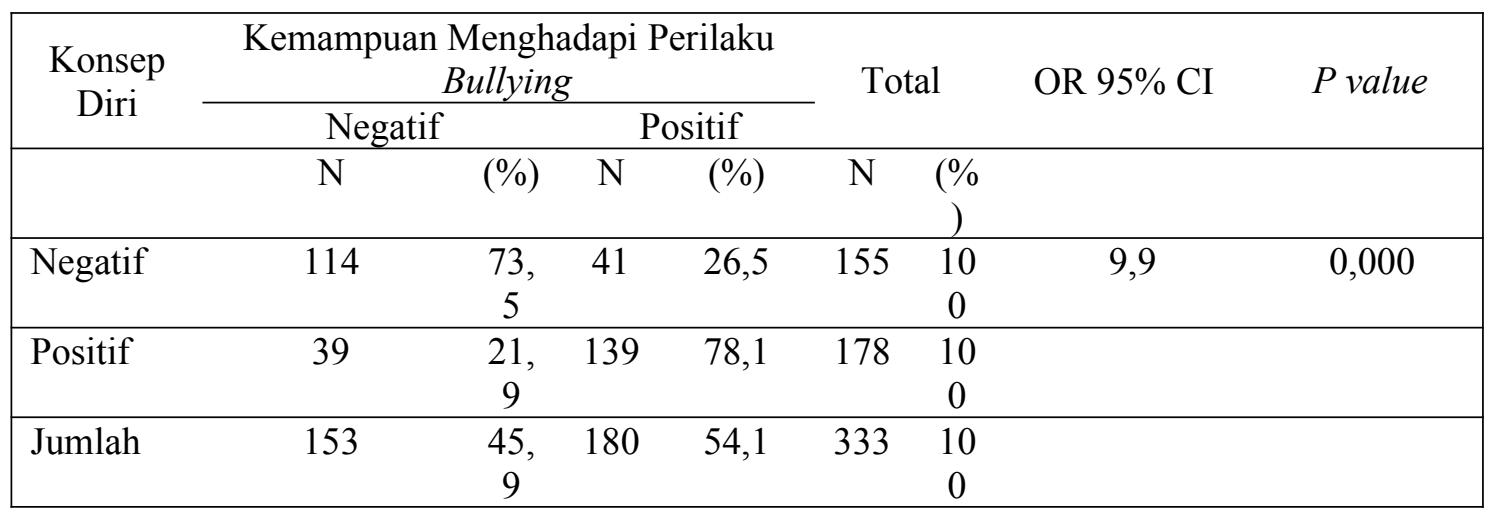

Berdasarkan tabel di atas didapatkan

Hasil penelitian menunjukkan bahwa hasil bahwa konsep diri pada remaja negatif terhadap kemampuan menghadapi perilaku bullying negatif sebanyak 114 orang $(73,5 \%)$ dan konsep diri pada remaja negatif terhadap kemampuan menghadapi perilaku bullying positif sebanyak 41 orang (26,5\%). Sedangkan konsep diri pada remaja positif terhadap kemampuan menghadapi perilaku bullying negatif sebanyak 39 orang $(21,9 \%)$ dan konsep diri pada remaja positif terhadap kemampuan menghadapi perilaku bullying positif sebanyak 139 orang $(78,1 \%)$.

Dari hasil uji statis bivariat menggunakan uji Chi Square yang telah dilakukan diperoleh $p$ value 0,000. Dari hasil tersebut diketahui nilai $\mathrm{p}<(0,05)$, sehingga H0 ditolak. Maka dari itu dapat disimpulkan bahwa terdapat hubungan yang signifikan antara konsep diri pada remaja terhadap kemampuan menghadapi perilaku bullying.

\section{PEMBAHASAN}

\section{Jenis kelamin} remaja yang bersedia menjadi responden yang paling banyak adalah berjenis kelamin lakilaki sebanyak 251 orang dengan persentase $75,4 \%$. Sedangkan remaja perempuan yang bersedia menjadi responden sekitar 82 orang dengan persentase 24,6\%. Disini menunjukkan bahwa mayoritas responden adalah laki-laki.

Bullying yang terjadi di sekolah menurut Riauskina, Djuwita, dan Soesetio (dalam Wiyani, 2012) yaitu perilaku agresif yang dilakukan oleh seseorang atau sekelompok orang yang memiliki kekuasaan terhadap siswa-siswi lain yang lebih lemah dengan tujuan menyakiti orang tersebut secara berulang kali. Artinya baik yang jenis kelamin laki-laki maupun perempuan berpotensi menjadi pelaku ataupun korban bullying sehingga pada penelitian ini tidak ada perbedaan untuk menjadi pelaku bullying atau menjadi korban bullying baik laki-laki maupun perempuan. Hal ini sependapat dengan penelitian yang dilakukan oleh Lili Fatmawati 
(2016) tentang perbedaan perilaku bullying ditinjau dari jenis kelamin bahwa tidak ada perbedaan perilaku bullying antara laki-laki maupun perempuan. Artinya siswa laki-laki maupun siswa perempuan sama-sama melakukan perilaku bullying.

\section{Konsep Diri Pada Remaja}

Dari penelitian yang dilakukan peneliti terhadap 333 responden, didapatkan hasil bahwa remaja yang memiliki konsep diri positif sebanyak 178 orang $(53,5 \%)$ dan remaja yang memiliki konsep diri negatif sebanyak 155 orang (46,5\%). Responden lakilaki yang memiliki konsep diri positif sebanyak 134 orang $(53,4 \%)$ dan reponden perempuan yang memiliki konsep diri positif sebanyak 44 orang $(53,7 \%)$.

Sobur (2011) berpendapat bahwa konsep diri adalah semua pemikiran kita tentang aspek pada diri yang meliputi aspek fisik, aspek sosial, dan aspek psikologis, yang semua tersebut berdasakan bagaimana pengalaman dan interaksi kita kepada orang lain. Selanjutnya dapat juga diartikan sebagai kesadaran batin yang tetap, mengenai pengalaman yang berhubungan dengan diri sendiri dan membedakan antara diri sendiri tersebut dengan orang lain.

Konsep diri pada remaja dipengaruhi oleh banyak hal, diantaranya adalah penampilan fisik, lingkungan keluarga, dan juga teman sebaya. Hal ini sesuai dengan Saam \& Sri (2012) bahwa konsep diri dipengaruhi oleh penampilan fisik, peranan keluarga, serta peranan kelompok teman sebaya.

Pernyataan diatas didukung oleh penelitian Susilowati (2011) bahwa kegemukan mempengaruhi konsep diri pada remaja. Kegemukan merupakan bagian dari penampilan fisik. Artinya penampilan fisik remaja mempengaruhi konsep diri pada remaja.

Konsep diri pada remaja di SMKN 2 Pekanbaru sebagian besar menunjukan hasil yang positif. Hal ini karena sebagian besar remaja di SMKN 2 Pekanbaru memiliki citra tubuh yang baik, ideal diri yang baik, harga diri yang baik, memiliki peran yang baik, dan identitas diri yang baik. Dengan konsep diri yang positif akan berdampak terhadap kemampuan menghadapi perilaku bullying.

\section{Kemampuan Menghadapi Perilaku Bullying}

Dari penelitian yang dilakukan peneliti terhadap 333 responden, didapatkan hasil bahwa remaja yang memiliki kemampuan menghadapi perilaku bullying positif sebanyak 180 orang $(54,1 \%)$ dan remaja yang memiliki kemampuan menghadapi perilaku bullying diri negatif sebanyak 153 orang (45,9\%). Responden laki-laki yang memiliki kemampuan menghadapi perilaku bullying positif sebanyak 141 orang $(56,2 \%)$ dan responden perempuan yang memiliki kemampuan menghadapi perilaku bullying positif sebanyak 39 orang (44,3\%). 
Muhammad Hadyan Nubli. M', Erna Marni², Yecy Anggreny ${ }^{3}$, Hubungan Konsep Diri Pada Remaja Terhadap Kemampuan Menghadapi Perilaku Bullying Di Smkn 2 Pekanbaru

Wiyani (2012) berpendapat bullying adalah perilaku yang tidak baik atau negatif yang dilakukan oleh seseorang atau sekelompok orang dimana hal tersebut bisa menyebabkan kerugian pada orang yang mendapat perlakuan negatif tersebut. Terdapat makna yang lebih luas dari bullying itu sendiri, mencakup berbagai bentuk kekuasaan atau kekuatan yang dipunya dengan tujuan menyakiti orang lain sehingga korban merasa tertekan, trauma, dan tidak berdaya. Bullying mengandung tiga unsur mendasar dari perilaku bullying yaitu bersifat menyerang secara agresif (seperti kontak fisik, verbal, maupun non verbal) dan negatif (merugikan orang lain).

Untuk menghadapi perilaku bullying diperlukan konsep diri yang baik. Salah satu bagian dari konsep diri yaitu harga diri. Apabila sudah terbentuk harga diri yang baik, maka perilaku bullying dapat dihadapi dengan baik pula. Hal ini sependapat dengan Surilena (2016) tentang perilaku bullying (perundungan) pada anak dan remaja bahwa dengan membantu remaja menumbuhkan harga diri yang baik, hal ini dapat membantu anak dalam menghadapi perilaku bullying. Remaja dengan harga diri yang baik akan lebih percaya diri, bersikap dan berperilaku positif, optimis, dan berani mengatakan haknya. Artinya yaitu, untuk dapat menghadapi perilaku bullying di sekolah, remaja harus memiliki konsep diri yang baik.

\section{Hubungan Konsep Diri Pada Remaja Terhadap Kemampuan Menghadapi Perilaku Bullying}

Hasil penelitian menunjukkan bahwa konsep diri yang buruk pada remaja terhadap kemampuan yang buruk dalam menghadapi perilaku bullying sebanyak 114 orang $(73,5 \%)$ dan konsep diri yang buruk pada remaja terhadap kemampuan yang baik dalam menghadapi perilaku bullying sebanyak 41 orang (26,5\%). Sedangkan konsep diri yang baik pada remaja terhadap kemampuan yang buruk dalam menghadapi perilaku bullying sebanyak 39 orang $(21,9 \%)$ dan konsep diri yang baik pada remaja terhadap kemampuan yang baik dalam menghadapi perilaku bullying sebanyak 139 orang $(78,1 \%)$.

Dari hasil uji statistis bivariat dengan menggunakan uji Chi Square yang sudah dilakukan, diperoleh $p$ value 0,000. Dari hasil tersebut diketahui nilai $\mathrm{p}<(0,05)$, sehingga H0 ditolak. Maka dari itu dapat disimpulkan bahwa terdapat hubungan yang signifikan "antara konsep diri pada remaja terhadap kemampuan menghadapi perilaku bullying". Saam dan Sri (2012) berpendapat bahwa konsep diri yang dimiliki setiap individu dapat menjadi positif ataupun negatif dengan intensitas yang berbeda beda. Jika seseorang memiliki konsep diri yang positif, maka akan mempunyai keyakinan bahwa ia mampu melakukan tugas tertentu sehingga akan cenderung terhadap keberhasilan, sedangkan seeorang dengan konsep diri negatif akan cenderung mempunyai harapan yang rendah 
terhadap keberhasilan usahanya. Artinya jika konsep diri seseorang positif, maka seseorang tersebut ketika melakukan suatu tugas tertentu akan cenderung terhadap keberhasilan, hal ini menunjukan jika seseorang dengan konsep diri positif maka seseorang tersebut akan cenderung juga berhasil dalam merespon bullying yang diterima. Hasil penelitian ini menunjukan bahwa sesuai dengan teori tersebut.

Peneliti berpendapat bahwa, penelitian ini ditemukan adanya hubungan konsep diri pada remaja terhadap kemampuan menghadapi perilaku bullying ini didasari oleh sebagian besar konsep diri yang baik sehingga memiliki kemampuan yang baik pula dalam menghadapi perilaku bullying yang diterima. Hasil analisa peneliti menunjukan bahwa untuk pernyataan konsep diri pada item harga diri tentang merasa malu ketika berbicara didepan umum menunjukan hasil negatif yang cenderung lebih tinggi dari pernyataan konsep diri lainnya. Pernyataan kemampuan menghadapi perilaku bullying pada item kontak fisik secara langsung menunjukan hasil negatif yang cenderung lebih tinggi dari pernyataan tentang kemampuan menghadapi perilaku bullying lainnya. Oleh karena itu diperlukan konsep diri yang lebih baik. Seseorang dengan konsep diri yang baik maka akan memiliki kemampuan untuk mencegah terjadinya perilaku bullying pada diri mereka sendiri. Hal ini sependapat dengan hasil penelitian Herdyanti \& Margaretha (2016) tentang hubungan antara konsep diri dengan kecenderungan menjadi korban bullying pada remaja awal yang menunjukan bahwa semakin positif konsep diri yang dimiliki remaja, maka semakin rendah kecenderungan yang dimiliki untuk menjadi korban bullying. Sebaliknya semakin negatif konsep diri yang dimiliki remaja, semakin tinggi kecenderungannya untuk menjadi korban bullying.

Konsep diri yang baik pada remaja akan berdampak terhadap penurunan kasus bullying di sekolah. Dalam hal ini peran guru dan keluarga serta lingkungan turut membantu agar terbentuknya konsep diri yang baik dan mencegah serta menangani bullying pada remaja terutama di sekolah. Hal tersebut sependapat dengan Surilena (2016) bahwa perlunya peran dari guru, orangtua, serta masyarakat dalam melakukan penanganan ataupun pencegahan bullying disekolah seperti membantu remaja agar dapat menumbuhkan harga diri yang baik. Anak atau remaja dengan harga diri yang baik akan lebih percaya diri, bersikap dan berperilaku positif, optimis, dan berani mengatakan haknya. Selanjutnya dengan membina komunikasi yang baik antara orangtua dan anak, mendiskusikan dengan anak terhadap pemahaman dan dampak bullying, mendukung remaja untuk berinteraksi dan bergabung dengan kelompok untuk melakukan kegiatan positif. Serta dapat menjadi model atau sebagai contoh panutan yang baik bagi remaja, bagaimana memperlakukan orang lain dengan hormat dan setara, menghargai dalam hal keberagaman dan keunikan orang lain. Dengan tercapainya 
Muhammad Hadyan Nubli. M⿻1, Erna Marni ${ }^{\mathbf{1}}$, Yecy Anggreny ${ }^{3}$, Hubungan Konsep Diri Pada Remaja Terhadap Kemampuan Menghadapi Perilaku Bullying Di Smkn 2 Pekanbaru

hal tersebut diharapkan remaja dapat dengan nyaman dalam melaksanakan kewajiban sebagai murid di sekolah yang nantinya dapat berdampak pada prestasi-prestasi yang diraih.

\section{SIMPULAN}

Hasil penelitian yang telah dilakukan tentang Hubungan Konsep Diri Pada Remaja Terhadap Kemampuan Menghadapi Perilaku Bullying di SMKN 2 Pekanbaru yaitu sebagian besar responden memiliki konsep diri positif. Dari hasil penelitian dan analisa peneliti untuk variabel tentang kemampuan menghadapi perilaku bullying di SMKN 2 Pekanbaru sebagian besar menunjukan hasil yang positif. Hasil penelitian menunjukan terdapat hubungan antara konsep diri pada remaja terhadap kemampuan menghadapi perilaku bullying dengan $p$ value $0,000<0,05$.

\section{SARAN}

Bagi peneliti selanjutnya dapat melakukan dengan metode kualitatif dengan mencari data yang lebih mendalam tentang konsep diri remaja korban bullying.

\section{DAFTAR PUSTAKA}

Abdullah, N. (2013). Meminimalisasi bullying di sekolah. MAGISTRA, 25(83), 50.

Dewi, H, E. (2012). Memahami Perkembangan Fisik Remaja. Yogyakarta: Gosyen Publishing.

Fatmawati, L., \& Uyun, Z. (2016). Perbedaan Perilaku Bullying Di Tinjau Dari Jenis Kelamin (Doctoral dissertation, Universitas Muhammadiyah Surakarta).
Herdyanti, F., \& Margaretha, M. (2016). Hubungan Antara Konsep Diri Dengan Kecenderungan Menjadi Korban Bullying Pada Remaja Awal. Jurnal Psikologi Undip, 15(2), 92-98.

Khoirunnisa, R. (2015). Konsep Diri Remaja Korban Bullying (Studi pada Siswa Korban Bullying di SMA Muhammadiyah 7 Yogyakarta). Jurnal Riset Mahasiswa Bimbingan Dan Konseling.

Komisi Perlindungan Anak Indonesia. (2016). Bully SMA 3, Kedatangan Tim KPAI Ditolak Pihak Sekolah. Jakarta : KPAI. Diperoleh dari http://www.kpai.go.id/berita/bully-sma-3kedatangan-tim-kpai-ditolak-pihak-sekolah/

Komisi Perlindungan Anak Indonesia. (2017). KPAI Terima Aduan 26 Ribu Kasus Bully Selama 2011-2017. Jakarta : KPAI. Diperoleh dari http://www.kpai.go.id/berita/kpai-terimaaduan-26-ribu-kasus-bully-selama-20112017/

Pendergrass, W. S., \& Wright, M. (2014). Cyberbullied To Death: An Analysis Of Victims Taken From Recent Events. Issues in Information Systems, 15(1), 134-136.

Saam, Z \& Sri, W. (2012). Psikologi Keperawatan. Jakarta: PT Raja Grafindo Persada.

Sobur, A. (2011). Psikologi Umum. Bandung: CV Pustaka Setia.

Soedjatmiko, S., Nurhamzah, W., Maureen, A., \& Wiguna, T. (2016). Gambaran bullying dan hubungannya dengan masalah emosi dan perilaku pada anak Sekolah Dasar. Sari Pediatri, 15(3), 17480.

Surilena. (2016). Perilaku Bullying (Perundungan) pada Anak dan Remaja. CDK-236, 43(1), 35-38.

Susilowati. (2011). Hubungan Kegemukan Dengan Konsep Diri Pada Remaja Usia 16-18 Tahun (Studi Analitik Di SMA Negeri 2 Pare). Jurnal AKP, 4, 43.

Wiyani, N. A. (2012). Save Our Children from School Bullying. Yogyakarta: Arruz Media.

World Health Organization. (2017). Mental Health Status of Adolescents in SouthEast Asia: Evidence for Action. Diperoleh dari 
Jurnal Ners Indonesia, Vol. 9, No. 1, September 2018

http://apps.who.int/iris/bitstream/handle/ 10665/254982/9789290225737-

eng.pdf;jsessionid $=\mathrm{E} 212548 \mathrm{CDFABCF} 5$

$\underline{\text { 8B308C2D731638EF5? sequence }=1}$ 